\title{
Alternative methods in toxicity testing: the current approach
}

\author{
Gabrielle Luck de Araújo ${ }^{1}$, Maria Augusta Amaral Campos ${ }^{1}$, Maria Anete Santana Valente ${ }^{2}$, Sarah \\ Cristina Teixeira Silva ${ }^{1}$, Flávia Dayrell França ${ }^{3}$, Miriam Martins Chaves $^{3}$, Carlos Alberto Tagliati ${ }^{1, *}$
}

\begin{abstract}
${ }^{1}$ Department of Clinical and Toxicological Analysis, School of Pharmacy, Federal University of Minas Gerais, Belo Horizonte, MG, Brazil, ${ }^{2}$ Department of Nutrition, Federal University of Juiz de Fora, Governador Valadares Campus, Governador Valadares, MG, Brazil, ${ }^{3}$ Department of Biochemistry and Immunology, Institute of Biological Sciences, Federal University of Minas Gerais, Belo Horizonte, MG, Brazil
\end{abstract}

\begin{abstract}
Alternative methods are being developed to reduce, refine, and replace (3Rs) animals used in experiments, aimed at protecting animal welfare. The present study reports alternative tests which are based on the principles of the 3Rs and the efforts made to validate these tests. In Europe, several methodologies have already been implemented, such as tests of irritability, cell viability, and phototoxicity as well as in vitro mathematical models together with the use of in silico tools. This is a complex process that spans from development to regulatory approval and subsequent adoption by various official entities. Within this regulatory framework is REACH, the European Community Regulation for chemicals and their safe use. In Brazil, the BraCVAM (Brazilian Center for the Validation of Alternative Methods) was recently established to validate alternative methods and stimulate incorporation of new methodologies. A new vision of toxicology is emerging for the 21 st century (Tox-21), and the subsequent changes are shaping a new paradigm.
\end{abstract}

Uniterms: Toxicology/alternative methods. Toxicological analysis/alternative methods. Toxicology/21st. century. Animals/use in experiments.

\begin{abstract}
Métodos alternativos estão sendo desenvolvidos para a redução, o refinamento e a substituição (3R) do número de animais utilizados em experimentos, visando ao seu bem-estar. Esses testes alternativos baseiam-se no princípio dos $3 \mathrm{R}$ e esforços têm sido empregados para que sejam validados. Na Europa, diversas metodologias já foram implantadas tais como: testes de irritabilidade, testes de viabilidade celular, testes de fototoxicidade e modelos matemáticos in vitro, além do uso de ferramentas in silico. Esse é um processo complexo, que abrange desde o seu desenvolvimento até a aceitação regulatória e posterior adoção por diversas organizações oficiais. No contexto regulatório está o REACH, o Regulamento da Comunidade Européia, para produtos químicos e sua utilização segura. No Brasil, o BraCVAM (Centro Brasileiro de Validação de Métodos Alternativos) foi recentemente estabelecido para validação de métodos alternativos e estímulo à incorporação de novas metodologias. Uma nova visão de toxicologia vem surgindo para o século XXI (Tox-21) e as mudanças ocasionadas promoverão um novo paradigma.
\end{abstract}

Unitermos: Toxicologia/métodos alternativos. Análise toxicológica/métodos alternativos. Toxicologia/ século 21. Animais/uso em experimentos.

\section{INTRODUCTION}

The development of alternative methods for animal

\footnotetext{
*Correspondence: C. A. Tagliati. Laboratório de Toxicologia Experimental, Departamento de Análises Clínicas e Toxicológicas, Faculdade de Farmácia, Universidade Federal de Minas Gerais. Av. Antônio Carlos, 6.627 - Campus Pampulha, 31270-901 - Belo Horizonte - MG, Brasil. Phone:+55-31-3409-6891, Fax:+55-31-3449-6895. E-mail: carlostagliati@ufmg.br
}

use, suggested by Russell and Burch (1959), has been prompted by concerns for animal welfare in laboratory experiments. some of the arguments raised by sectors of society have been based on the fact that alternative methods are able to replace the use of animals in research, a practice that is today considered obsolete. However, the idea is not to completely abolish the use of animals in research, as this could pose a risk to the advancement of 
biological knowledge, testing, and development of new drugs, vaccines, and surgical methods (Morales, 2008; Rogiers, 2005).

Increased interest and daily advances within the scientific community has brought about the development of alternative methods in an attempt to reduce, replace, and refine the number of animals used in laboratory experiments, thus lowering the expenses incurred with the purchase of animals used in research (Hartung, 2011).

Currently, efforts are being made toward validating alternative tests. A reassessment of the use of animals in laboratory experiments is a worldwide trend, as evidenced in several countries by the founding of various institutions aimed at developing and validating new methods, regulations, and means by which to implement alternative tests in an attempt to legalize and standardize their use (Russel, Burch, 1959; Schechtman, 2002; GIBB, 2008; Balls, 1994). In this context, the knowledge pertaining to alternative tests and their use has been progressing.

The use of these alternative methods has become essential, given that they allow for a reduction in the number of animals used in laboratory experiments, for improvements in toxicological procedures that are less painful or stressful for the animals when undergoing tests, or for the replacement of tests on animals by in vitro and ex vivo tests or in silico systems (Kandárová, Letasiová, 2011).

Since 2007, a new vision of toxicology for the 21st century (Tox-21 c) has been under debate (NRC) and is highly prevalent within the scientific community. These changes will most likely bring about a new paradigm in toxicology (Hartung, 2011).

Nonetheless, the enormous breakthrough that has occurred in this sector in recent years has mainly been due to government initiatives, in the form of government agencies responsible for the regulation and recognition of in vitro tests.

The aim of the present review was to address the main points concerning alternative methods, considering governmental initiatives and studies based on the $3 \mathrm{Rs}$ philosophy.

\section{REGULATORY AGENCIES}

Concerted efforts have been made in the search for new alternatives. In 1989, in Germany, the ZEBET (Zentrealstelle ErfassungBewertung von zur Ersatz und zum Erganzungsmethoden Tierversuch - National Center for the Documentation and Evaluation of Alternatives for Methods of Animal Experimentation) was created, whereas in 1993, the community established the
European ECVAM (European Center for the Validation of Alternative Methods) (Spielmann, 2002).

In 1997, US government agencies formed the ICCVAM (Interagency Coordinating Center for the Validation of Alternative Methods). The ICCVAM consists of 15 research and regulatory agencies, among which number the Environmental Protection Agency (EPA), the Food and Drug Administration (FDA), and the Agency for Toxic Substances and Disease Registry (ATSDR). These organizations provide or use toxicological information for risk assessment processes. The Committee, through these federal agencies, seeks to coordinate discussions on the development, validation, and approval, in addition to national and international standardization, of toxicological tests (Iccvam, 1999, 2001, 2003).

In 2005, the Japanese government created the JaCVAM (Japanese Center for the Validation of Alternative Methods) while in 2011 BraCVAM (Brazilian Center for the Validation of Alternative Methods) was founded in Brazil. This center is the result of cooperative efforts between the Oswaldo Cruz Foundation (FIOCRUZ) and the Brazilian National Sanitation Agency (ANVISA, 2011).

In addition to the BraCVAM, the Ministry of Science, Technology, and Innovation (MCTI) established the National Network of Alternative Methods, which will be coordinated by the BraCVAM and INMETRO (National Institute of Quality Metrology, Standardization, and Industrialization). These efforts are aimed at bringing together groups of Brazilians working in this line of research. Once the BraCVAM has become fully functional, it is expected to develop research collaborations with similar centers worldwide (ANVISA, 2011).

Many previous initiatives will be exploited by BraCVAM, as one of its goals is to validate alternative methods that have been recognized throughout Europe and in the United States, as well as to encourage and incorporate new methodologies, through a process known as validation by capture. For Brazilian products in particular, such as antiophidic serum, it is intended to develop new forms of quality control which, if implemented, will also require the development of methodologies to validate these approaches within the context of national standards (Sustainable Planet, 2011).

Activities carried out by these governmental institutions focus on superseding the regulatory tests conducted on animals to identify toxic properties of chemical substances to which humans or the environment are exposed (Seidle, Stephens, 2009; Spielmann, 2002).

Currently, governmental initiatives are important to foster the development of the new methods and validate those already available. 


\section{R PHILOSOPHY}

Alternative tests are part of the philosophy known as the "3R philosophy" (i.e. Replacement, Refinement, and Reduction) as regards animal testing, a fact cited in the first chapter of the document "Recognition and Alleviation of Pain in Laboratory Animals", published by the National Research Council in 2009 (NCR, 2009).

After the introduction of several alternative methods, such as modeling (Q) SARs (Quantitative StructureActivity Relationship), the Organization for Economic Cooperation and Development (OECD) published reports and guides regarding validation (Cazarin et al., 2004). Some specific facts from these reports are noteworthy, such as replacing the OECD 401 guideline (acute toxicity) with the 420,423 , and 425 Guidelines, as well as the introduction of Guideline 428 (on dermal absorption) as an alternative to Guideline 427. These examples pertain to the refinement and reduction of animal experiments, especially as described in the document "OECD Considerations on Animal Welfare in the Development of Test Guidelines".

For cosmetic products, a current emerging reality, animal testing was set to be banned by 2003 , following the $7^{\text {th }}$ EU Directive on cosmetics (76/768/EEC) in 2003, animal testing was set to be banned by 2013 . Since then, the ECVAM has been providing annual technical reports on the processes undertaken for the development, validation, and regulation of alternative methods in an attempt to meet the policy deadlines (ECVAM, 2010).

The $3 \mathrm{R}$ philosophy not only started this process, but has prompted many sectors of society, academy and government to develop potential methods for reducing the use of animals in research.

\section{REGISTRATION, EVALUATION, AUTHORI- ZATION, AND RESTRICTION OF CHEMICALS (REACH)}

After the 7th EU Directive, the Registration, Evaluation, Authorization, and Restriction of Chemicals $(\mathrm{REACH})$ regulation was established. REACH is the European Community Regulation on chemicals and their safe use. It deals with the Registration, Evaluation, Authorisation and Restriction of Chemical substances. The law was enacted on June, $1^{\text {st }} 2007$. The aim of REACH is to improve the protection of human health and the environment through more effective and earlier identification of the intrinsic properties of chemical substances. In parallel, REACH also aims to enhance innovation and competitiveness of the EU chemicals industry. The benefits of the REACH system will become apparent gradually, as more and more substances are phased into REACH (European Commission Environment, 2012).

With great scientific and technological innovations plus numerous new products, the market has grown rapidly. Thus, it is impossible to determine the toxicological profile of every product on the market, especially considering the current methods of toxicological evaluation. Nearly all of the provisions proposed by REACH are discussed within chemical industries worldwide, which boast some of the largest companies in the world (Brown, 2003).

The REACH Regulation places greater onus on industry to manage the risks from chemicals and to provide safety information on the substances. Manufacturers and importers are required to gather information on the properties of their chemical substances, which will allow their safe handling, and to register the information in a central database run by the European Chemicals Agency (ECHA) in Helsinki. The Agency acts as the central hub of the REACH system: it manages the databases necessary to operate the system, co-ordinates the in-depth evaluation of suspicious chemicals and is building up a public database in which consumers and professionals can find hazard information (Lilienblum, 2008).

Since 2004, the European Union has rejected the practice of using guinea pigs in producing cosmetics for the beauty market. During 2008 and 2009, ECVAM expanded its activities related to the development, validation, and optimization of alternative methods. Moreover, over the past two years, ECVAM has also become highly active in the regulation of alternative methods (ECVAM, 2010). Therefore, several international organizations support the use of alternative methods for toxicological tests, as well as extensive chemical and pharmaceutical support, because, in addition to the issue of ethics, the financial nature of this shift is quite favorable (Brown, 2003).

Concerned about this trend, some industries and universities in Brazil have invested in research and development aimed at abolishing animal testing, primarily in the production of cosmetics (ANVISA, 2011).

\section{INITIATIVES FOR THE ADVANCEMENT OF ALTERNATIVE METHODS}

To support this process, a report, commissioned by the European Commission, was recently published, providing a comprehensive overview of the alternative methods available to potentially replace animal testing in safety assessments of cosmetics, pharmaceuticals, and chemicals. The review includes five main areas: 
toxicokinetics, dermal sensitization, repeated dose toxicity, carcinogenicity, and reproductive toxicity (Schmidt, 2009).

Hartung (2011), together with 16 experts from the US, Europe, and Japan, assessed this report. Some of these authors' input may provide data that are suitable as a replacement for some animal studies in the future. Experts estimate that the replacement of animal experiments will be possible for aspects of skin sensitization and toxicokinetics in approximately 5-9 years. However, within 10 years, this replacement will be required for other areas as well.

Alternative methods present advantages, such as lower cost and time savings. Several learning centers in Brazil are using this methodology, however it is still undergoing evaluation. There are relatively few disadvantages of this alternative. Experts point out that, in some cases, the absence of interaction of a test substance with a living organism can impact results. However, in this case, with the advancement of scientific knowledge, this factor will soon be eliminated.

Some alternative methods, although not yet validated, are being developed and are supported at various research centers, such as the Committee on Alternative Tests from the Brazilian College of Animal Experimentation (Cobea) and the Pasteur Institute in São Paulo.

The use of in vitro Myography to replace lethality (LD50) tests using botulinum toxin (botox) is currently being performed on live animals in research conducted in the Department of Pharmacology, School of Medicine, the State University of Campinas (Bittencourt, 2012). Epidemiological and clinical studies, autopsies, and postmortem studies, as well as computer simulations and the use of mathematical models are also important tools in creating alternative methods.

Currently, all initiatives toward developing methods which can promote Replacement, Refinement, and Reduction, including working groups and Committees, are important to provide robust methods.

\section{TWENTY-FIRST CENTURY TOXICOLOGY (TOX-21C)}

In 2007, the National Research Council (NRC) published the report "Toxicity Testing in the $21{ }^{\text {st }}$ Century: A Vision and a Strategy" in an attempt to develop a long term vision for toxicity testing and outline a strategic plan to accomplish this. The new approach to toxicity testing demanded fewer animal studies and focused on in vitro methods for assessing risks that chemicals may pose to biological systems (Schmidt, 2009).

In 2008, a partnership was forged involving the National Toxicology Program (NTP), the National Institute of Health Chemical Genomics Center (NCGC), and the Environmental Protection Agency (EPA) to establish the Tox-21 program, aimed at promoting the advancement of toxicity tests. Each agency contributes with experience, resources, and tools to develop faster and more efficient approaches for predicting how chemicals can affect human health (Schmidt, 2009).

The Tox-21 proposes mapping a complete set of biochemical pathways involved in biological responses. Therefore, identification of the impairment from toxicity allows, the potential for human injury caused by chemicals to be inferred, i.e. the adverse effect or disease that would affect the human body if exposed to toxic substances (Collins et al., 2008).

Toxicity Testing in the $21^{\text {st }}$ Century envisions a notso-distant future where virtually all routine toxicity testing will be conducted on human cells or cell lines in vitro by evaluating disturbances in cellular responses (Andersen, Krewski, 2009).

Currently, Tox-21 is a very important program to develop Toxicology as a science and a tool for evaluating the safety of substances because it addresses an issue which is weak in this area: mechanism of action. For example, it is very common to evaluate the structure-activity relationship (Pharmacology), yet very unusual to investigate the structure-toxicity relationship (Toxicology).

\section{ALTERNATIVE TESTS}

In vitro tests offer several advantages, including controlled testing conditions; a high level of standardization; a reduction in variability between experiments; the absence of systemic effects; low cost testing; a small amount of material needed; a limited amount of toxic waste, cells, and human tissues used; as well as transgenic cells carrying human genes; and reduced animal testing.

However, the limitations of in vitro tests raise numerous questions, as discussed by Kandárová and Letasiová (2011). Questions include: How can the interactions between tissues and organs be tested? Can systemic effects be assessed? How can the pharmacokinetics be evaluated? How can the chronic effects be tested? In addition, there are also technical limitations involved: solubility and reaction to plastics. The following sections present some methods currently used for in vitro testing. 


\section{Cell and tissue cultures}

Cell and tissue cultures are also widely used in basic applied research. For example, studies into the effect of chemotherapy on the viability of cancer cells. These experiments are the basis for determining a drug's potential to eliminate cancerous cells. Toxicity tests of some substances can also be carried out in cell cultures. Such assays support knowledge on whether or not a newly discovered drug or substance is toxic to cells in the human body (Wilmes et al., 2011).

Cells in culture are easy to handle and observe from microscopic, biochemical, and molecular viewpoints after the addition of substances within which these cells are cultured. However, this same substance tested on cells must be previously studied for the cells' behavior when applied to a living organism (in experimental animals, especially mammals), given that, in vivo, many factors can interfere with the body's own responses.

Nevertheless, prior in vitro studies have helped toward reducing the number of animals used in research. One concrete example of the use of human tissues in research is the pituitary gland. Growth hormones were extracted from the glands of deceased donors to be used in the treatment of children with impairments in the production of this hormone. This practice fell into disuse after finding contamination of some children with infectious diseases stemming from the donor (Jung et al., 2009).

Bioengineering, using the bacterium Escherichia coli provides more efficient production of this hormone without the risk of contamination from donors. Moreover, tissues collected from breast biopsies can be used to study the development of cancer within the organ. Likewise, cells derived from tissues of other organs can be used for many different scientific purposes (Feist, Palsson, 2008).

\section{Toxicity tests}

\section{Cell Viability Test}

Cell viability tests consist of substances added to the culture mediums of specific cells in which some parameters of viability (or damage their membranes at their junction) are tested (Morales, 2008). Cell cultures drawn from different tissues can be used, and toxicity tests of various substances may be performed. Cell viability and damage to its structure are measures used in the analysis of specific parameters, such as toxicity. During development and reproduction, the toxicity test can be performed in chicken embryos, fish, and amphibians. This technique has proven to be very important (Blanton, 2007).
Recommendations from the OECD to reduce the use of animals are listed under guideline number 129/2009Guidance document on using cytotoxicity tests to estimate starting doses for acute oral systemic toxicity tests. This document describes the methods needed to determine the in vitro cytotoxicity of basal substances using neutral red uptake (NRU) and in vitro data to determine starting doses for oral toxicity in vivo.

A dose-response test is performed to determine the NRU concentration, which is reduced by $50 \%$ when compared to the controls (e.g., IC50). The IC50 value is used in a linear regression equation to estimate the value of LD50 by the oral route, which is then used to determine an initial dose for acute oral toxicity tests using rats.

The use of NRU in an approach to determine the starting dose for acute oral doses can reduce the number of animals needed for tests and substances needed to determine toxicity. To calculate the initial doses, in vitro data should be considered along with all other quantitative data and information, such as structureactivity relationship (QSAR), the LD50 of related substances, and other data necessary to estimate the dose which most closely resembles to the real value of LD50.

\section{Tests for ocular irritability}

In the past, tests on substances that cause irritability were commonly performed by applying the substance directly on the cornea of rabbits (Draize test) (Draize et $a l .$, 1944). Several tests have been developed to replace this practice; some are indicated below (Bradlaw, Wilcox, 1997).

Hen's egg test on the chorioallantoic membrane HET-CAM: using fertilized chicken eggs to assess irritability of the chorioallantoic membrane, which contains a large number of blood vessels (Luepke, 1985).

Hemolysis test or Red Blood Cell (RBC): evaluates the phenomena of hemolysis and protein denaturation, resulting from the action of the test substance (Pape et al., 1987).

Bovine corneal opacity and permeability (BCOP). This method has been fully validated by international bodies (OECD guideline 437, 2009). The BCOP assay was developed as an alternative to the ocular dermal irritation test in rabbits (Draize) (Iccvam, 2003; Gibbs, 1985).

Isolated rabbit or chicken eye test: eyes isolated from dead animals (which were discarded) are tested for edema and corneal opacity, as well as retention of fluorescence, after exposure to the test substance (Morales, 2008).

\section{Phototoxicity}

The OECD also recommends testing Phototoxicity 
TABLE I - Characteristics of in vitro assays

\begin{tabular}{ll}
\hline Assay & General description \\
\hline Neutral Red Uptake & $\begin{array}{l}\text { Target cells (primary or continuous; fibroblasts } \\
\text { or epithelial-like) are grown in submerged } \\
\text { monolayer culture }\end{array}$ \\
\hline
\end{tabular}

BCOP

Living bovine corneas are treated with test material and changes in opacity and permeability are measured by instruments.
Method of applying test material

Generally increasing dilutions of test material are added to growth medium until a predetermined end point (generally cytotoxicity) is reached. e.g. raw material, topical product

Test materials are applied neat or at in-use concentrations directly to the epithelial surface of the cornea. e.g. products used in the area of the eyes, shampoos, conditioners.

Test materials are applied neat or at in-use concentrations directly to the membrane and damage to the membrane is recorded. e.g. products used in the area of the eyes, shampoos, conditioners

Dilutions of test material used; lysis (release of hemoglobin) and hemoglobin denaturation are monitored. e.g. surfactants used in shampoos and liquid soaps

This test is used to identify the phototoxic potential of a test substance induced by the excited chemical after exposure to light. Dilutions of test material are used. e.g. raw material, topical product. in vitro (Guideline 432, 2004). This protocol is used to identify the phototoxic potential induced by chemicals after exposure to light. The test is evaluated by the relative reduction in cell viability when exposed to chemicals, in the presence versus absence of light. Substances identified in this test are likely to be phototoxic in vivo after systemic application and distribution on skin or topical application. The in vitro 3 T3 NRU phototoxicity test was shown to be predictive of acute phototoxicity effects in animals and humans in vivo.

\section{Mathematical models}

Mathematical models can contribute to experimental work by defining variables and testing theories, reducing the cost of these experiments and rendering them more effective. One example is, the use mathematical models of the protein structure to, predict its physical and chemical properties (Ritchey, 2012).

Tests on irritability could benefit from these studies; however, despite contributing toward decreasing the number of animals used, this methodology does not preclude final tests on animals or biological substitutes (e.g. fertilized egg chicken cell culture). It is always important to remember that computers process and store existing knowledge, much of which was acquired through the use of research on animals (Morales, 2008).

\section{In silico}

The advantages of in silico tools are unquestionably costs, standardization, and minimal equipment needs. These tools can also be easily integrated with other tools in integrated testing strategies. The limited public availability of these data, the lack of homogeneity of data sets, and selection bias of the data provided may well compromise modeling (Hartung, 2011). The application of molecular biology contributes to scientific breakthroughs in this line, including contributing to the assessment of health risks caused by potentially toxic chemicals (Gibb, 2008).

\section{FINAL CONSIDERATIONS}

The evaluation of substance toxicity has seen remarkable progress mainly, due to the regulatory agencies, such as ECVAM and ICCVAM. Thus, we hope BRACVAM can play an important role in this context. Currently, recognition by governments of the need to fost the development of $3 \mathrm{R}$ philosophy has been critical to this process, as has Tox 21, which aims to promote the 
advancement of toxicity. These initiatives are in response to new demand, such as REACH, which aims to identify the intrinsic and toxicological properties of substances. Hence, the need to develop methods for evaluating the safety of substances has become an important issue. Therefore, several alternative tests are being developed and used as tools for preliminary assessments, such as physicochemical properties, structure-activity relationships, and the use of computer models, as well as in vitro and ex vivo tests. In addition, many working groups have been striving to debate new alternative methods. While alternative methods do help to reduce the number of animals required for drug research, there is no way they can completely eliminate the need for animals in preclinical studies at the present time. However, many of these in vitro tests are still unable to reliably predict toxicity in vivo. Based on this view and the trend toward international standardization, both the validation and implementation of alternative methods require the involvement of several regulatory agencies, which must assume the responsibility for guiding the process of developing new methodologies.

\section{ACKNOWLEDGEMENTS}

The authors would like to thank IM-INOFAR/ $\mathrm{CNPq}-$ Brazil and FAPEMIG for financial support.

\section{REFERENCES}

ANVISA 2011. Agência Nacional de Vigilância Sanitária. Reunião Aberta ao Público. < No 09/2011http://portal. anvisa.gov.br/>. Accessed on 9 feb. 2012.

BALLS, M. Replacement of animal procedures: alternatives in research, education and testing. Lab. Animals, v.28, p.193$211,1994$.

BITTENCOURT, M.K.W et al. Evaluation of the efficacy and safety of botulinum toxin type A to induce temporary ptosis in dogs. J. Ocular Pharmacol. Ther. v.29, p.431-436, 2012.

BRADLAW, J. A.; WILCOX, N. L. Workshop on eye irritation testing: practical applications of non-whole animal alternatives. Food Chem. Toxicol., v.35, p.1-11, 1997.

BROWN, V. J. Reaching for chemical safety. Environ. Health. Perspct., v.111, n.14, 2003.
CAZARIN, K.C.C.; CORRÊA, C.L.; ZAMBRONE, F.A.D. Redução, refinamento e substituição do uso de animais em estudos toxicológicos: uma abordagem atual. Braz. J. Pharm. Sci., v.40, n.3, p.289- 299, 2004.

COLLINS, F.S.; GRAY, G. M.; BUCHER, J. R. Transforming enviromental health protection. Science, v.319, p.906-907, 2008.

DRAIZE, J. H.; WOODARD, G.; CALVERY, O. H. Methods for the study of irritation and toxicity of substances applied topically to the skin and mucous membranes. J. Pharm. Expt. Ther., v.83, p.377-390, 1944.

ECVAM. (2009).Technical Report on the Status of Alternative Methods for Cosmetics Testing (2008-2009) A report prepared in the framework of Directive 2003/15/ EC ( 7 th Amendment to the Cosmetics Directive). European Commission Environment $<\mathrm{http}$ ://ec.europa.eu/ environment $/ \mathrm{chemicals} / \mathrm{reach} / \mathrm{reach}$ intro.htm $>$. Acessed on 08 dec. 2012.

GIBBS, C.J.; JR, J. A.; HEFFNER, R.; FRANKO, M.; MIYAZAKI, M.; ASHER, D. M.; PARISI, J.E.; BROWN, P. W.; GAJDUSEK, D. C. Clinical and pathological features and laboratory confirmation of Creutzfeldt-Jakob disease in a recipient of pituitary-derived human growth hormone. $N$. Engl. J. Med., v.313, p.734-738, 1985.

GOLDBERG, A.; MCCULLEY, J. P. Alternative methods in toxicology. 1st Ed.4, New York: Mary Ann Liesbert; 1987.

HARTUNG, T. From alternative methods to a new toxicology. Eur. J. Pharm. Biopharm., v.77, p.338-349, 2011.

ICCVAM 1999 (interagency coordinating committee on the validation of alternative methods). Evaluation of the validation status of toxicological methods: General guidelines for submissions to ICCVAM. [S.1.]: National Institute of Health, rev. out, 1999. NIH Publication No. 99-4496. Disponível em: <http://iccvam.niehs.nih.gov/ docs/guidelines/subguide.htm>. Acessed on 05 jun. 2003.

ICCVAM 2001 (Interagency Coordinating Committee On The Validation Of Alternative Methods). Annual Progress Report. [S.1.]: National Institute of Health, 2001. <http:// iccvam.niehs.nih.gov/about/annrpt/annrpt01.pdf $>$. Accessed on 07 jul. 2003. 
ICCVAM 2003 (Interagency Coordinating Committee on the Validation of Alternative Methods). The national toxicology program interagency center for the evaluation of alternative toxicological methods 2003. <http://iccvam.niehs.nih.gov>. Accessed on 07 jul. 2003.

KANDÁROVÁ, H; LETASIOVÁ, S. Alternative methods in toxicology: re-validated and validated methods. Interdiscip. Toxicol., v.4, p.107-113, 2011.

LILIENBLUM, W.; DEKANT, W.; FOTH, H.; GEBEL, T.; HENGSTLER, J. G.; KAHL, R.; KRAMER, P.-J.; SCHWEINFURTH, H.; WOLLIN, K.-M. Alternative methods to safety studies in experimental animals: role in the risk assessment of chemicals under the new European Chemicals Legislation (REACH). Arch. Toxicol., v.82, p.211-236, 2008.

LUEPKE, N. P. Hens egg chorioallantoic membrane test for irritation potential. Food Chem. Toxicol., v.23, p.287-291, 1985.

MORALES, M. M. Métodos alternativos à utilização de animais em pesquisa científica: mito ou realidade? Ciênc. Cult., v.60, p.30-35, 2008.

NCR (National Research Council). Recognition and alleviation of pain in laboratory. Washington DC, 2009, NCR.

OTA (Office of Technology Assessment). Alternatives to animal use in research, testing and education. Washington DC, 1986 Ota Publ. No OTA-BA-273.

Planeta sustentável < http://planetasustentavel.abril.com. br/noticias/pais-tera-centro-pesquisas-animais-639997. shtml>. Accessed on 11 dec. 2011.
RAMOS, O. H.; SELISTRE-DE-ARAUJO, H. S. Comparative analysis of the catalytic domain of hemorrhagic and non-hemorrhagic snake venom etallopeptidases using bioinformatic tools. Toxicon., v.44, p.529-538, 2004.

ROGIERS, V. Recent developments in the way forward for alternative methods: Formation of national consensus platforms in Europe. Toxicol. Appl. Pharmacol., v.207, p.408-413, 2005.

RUSSEL, W. M. S.; BURCH, R. L. The principles of humane experimental technique. London: Methuen, 1959.

SCHECHTMAN, L.M. Implementation of the 3Rs (Refinement, reduction, and replacement): Validation and regulatory acceptance considerations for alternative toxicological test methods. Ilar. J., v. 43, p.85-94, 2002.

SCHMIDT, C. W. TOX 21: New Dimensions of Toxicity Testing. Environ. Health Perspct., v.117, p.A348-A353, 2009.

SPIELMANN, H. Animal use in the safety evaluation of chemicals: harmonization and emerging needs. Ilar, J., v.43, p.11-17, 2002.

WOLFGANG, J. W. P.; PFANNENBECKER, U.; HOPPE, U. Validation of red blood cell test system as in vitro assay for the rapid screening of irritation potential of surfactants. Mol. Toxicol., v.1, p.525-536, 1987.

Received for publication on $03^{\text {rd }}$ April 2013 Accepted for publication on $16^{\text {th }}$ September 2013 